\title{
Healthcare providers' knowledge on rotavirus vaccine at selected primary healthcare centers in Erbil City
}

Accepted: 12/8/2015

\begin{tabular}{|c|c|}
\hline \multicolumn{2}{|c|}{ Kaify Jamil Qadir * } \\
\hline \multicolumn{2}{|c|}{ Abstract } \\
\hline \multicolumn{2}{|c|}{$\begin{array}{l}\text { Background and objective: Rotavirus gastroenteritis is the most common cause of } \\
\text { acute dehydrating diarrhoea among children younger than five years and globally the } \\
\text { most important cause of severe diarrhea in this age group. Most children acquire rotavirus } \\
\text { infection before they turn two years of age. Rotavirus vaccination can prevent rotavirus } \\
\text { infection. This study aimed to assess healthcare providers' knowledge regarding rotavirus } \\
\text { vaccine. } \\
\text { Methods: A cross-sectional descriptive study was conducted on } 100 \text { healthcare providers } \\
\text { at four healthcare centers (Azady, Tayrawa, Mala Fandi and Zhyian), during July to August } \\
2014 \text {. Data were collected through the use self-reporting questionnaire format, which was } \\
\text { developed for the purpose of the study. A socio-demographic sheet was also constructed } \\
\text { to determine characteristics of the subjects. } \\
\text { Results: Most of the healthcare providers were in the age group } 33-42 \text { years old (31\%), } \\
51 \% \text {, were male, } 80 \% \text { were married, } 56 \% \text { were graduated from the institute, half of them } \\
\text { had work experience between } 2-11 \text { years and } 29 \% \text { were working in vaccination room. Fifty } \\
\text {-four (54\%) of healthcare providers had average knowledge while } 24(24 \%) \text { and } 22(22 \%) \\
\text { of them had a poor and good knowledge, respectively. } \\
\text { Conclusion: More than half of healthcare providers had average knowledge regarding } \\
\text { rotavirus vaccine. } \\
\text { Keywords: Healthcare Providers; Knowledge; Rotavirus Vaccine. }\end{array}$} \\
\hline itroduction & rotaviruses. For example, rotavirus \\
\hline $\begin{array}{l}\text { Viral gastroenteritis causes approximately } \\
80 \% \text { of all cases of diarrhea in children } \\
\text { younger than one year with rotavirus } \\
\text { accounting for } 50 \% \text { of the cases of acute } \\
\text { diarrhea in children. Rotavirus is the } \\
\text { most common cause of diarrhea illness } \\
\text { among children worldwide and accounts for } \\
\text { approximately one-third of hospitalizations } \\
\text { of children in industrialized countries. It } \\
\text { is estimated that by five years of } \\
\text { age, nearly every child will have had at } \\
\text { least one episode of rotavirus-induced } \\
\text { illness. }{ }^{1} \text { According to the World Health } \\
\text { Organization, } 46 \% \text { of severe diarrhoea } \\
\text { cases are caused by rotavirus and the rota- } \\
\text { virus is the second cause of death among } \\
\text { infants in Iraq. }{ }^{2} \text { However, several studies } \\
\text { from different Iraqi governorates have } \\
\text { shown different results about infectivity with }\end{array}$ & 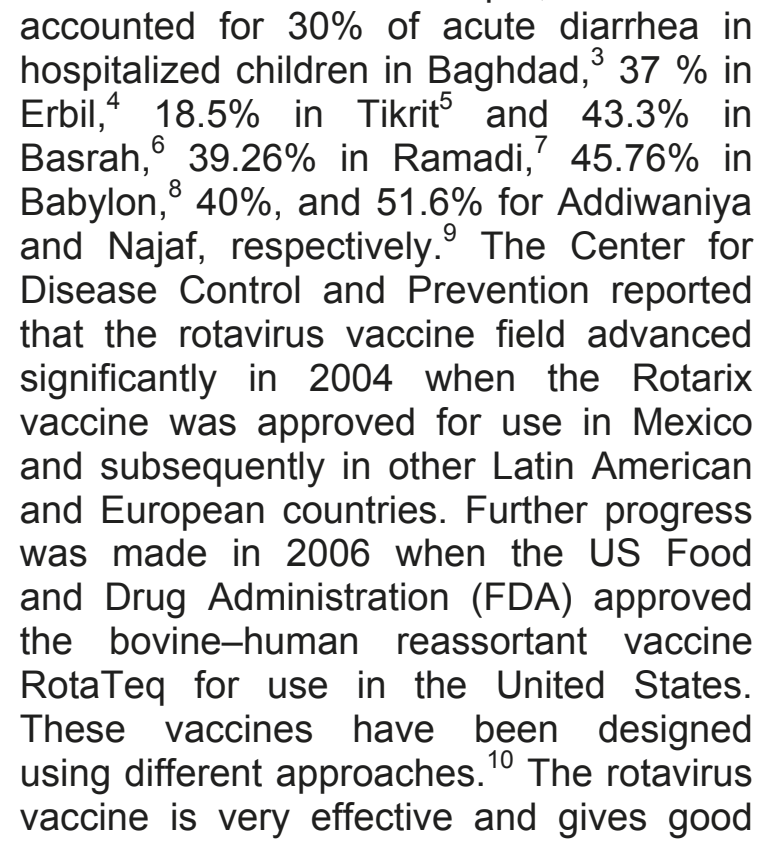 \\
\hline
\end{tabular}


immunity to rotavirus infection. Efficacy studies have demonstrated that rotavirus vaccine is $85 \%-98 \%$ protective against severe rotavirus disease and $74 \%-87 \%$ protective against rotavirus disease of any severity in the first year after vaccination. ${ }^{1}$ The Strategic Advisory Group of Experts on Immunization stated that healthcare provider is the best source of information on the benefits and risks of vaccines. Before the child receives a dose of any vaccine, discuss with the health care provider any health problems that the child may have and any medications that the child is currently taking or has been prescribed. ${ }^{11}$ Healthcare professionals should advise the parent that rotavirus causes about half of all episodes of hospitalized gastroenteritis in infants and young children. Rotavirus vaccine is the best way to protect children against rotavirus disease. The overall benefits of preventing gastroenteritis from rotavirus are much greater than the small risks or complication. ${ }^{12}$ The Ministry of Health, Iraq has introduced Haemophilus influenzae type B and Rotavirus vaccine in national immunization schedule from January 2012. These vaccines along with the other vaccines are now available for the target children at all health care centers. The Minister of Health of Iraq reported that these vaccines would protect thousands of infants in Iraq against the most dangerous childhood infections, including the major causes of diarrhoea and the major causes of pneumonia, and meningitis, known to lead to severe neurological disabilities. ${ }^{2}$ This study aimed to assess healthcare providers' knowledge regarding rotavirus vaccine and to find out the association between healthcare providers' knowledge with socio-demographic variables.

\section{Methods}

\section{Design and setting}

A cross-sectional descriptive study was carried out at four primary healthcare centers (PHCC) in Erbil city; Azadi,
Malafandi, Tairawa and Zhian. There are several services provided to the people by PHCCs such as; antenatal care, growth monitoring, expanded program of immunization, oral rehydration, laboratory investigations, radiology, dentistry, family planning and labor services.

\section{Study sample}

A non-probability convenience sample was used for selecting the sample. In each PHCC a questionnaire was distributed among all healthcare providers working in vaccination, malnutrition, family planning, pharmacy, laboratory and birth registration units. One hundred questionnaire forms were filled by healthcare providers $(35,17$, 28 and 20 in Azady, Malafandi, Tayrawa and Zhyian,respectively ). Inclusion criteria included having more than one year experience in PHCCs and willingness to participate in the study.

\section{Data collection tool}

Through the review of related literature, a questionnaire was constructed by the investigator and distributed among healthcare providers in selected PHCCs as self-reporting. It was comprised of two major parts;

1. Socio-demographic information of subjects: age, gender, qualification, marital status, years of experience, and working place in PHCCs.

2. Questions concerning healthcare providers' knowledge on rotavirus vaccine: it consists of 16 questions which cover the most important issues regarding rotavirus vaccine. It was organized as multiple choices; a corrected answer was given 1 score but a wrong one was given zero scores. Finally, the acquired scores for each one were converted to 100 degree by a formula.$^{13}$

$$
\frac{\text { part }}{\text { whole }}=\frac{\%}{100}
$$

For example if one got 12 score:

$$
\left.\frac{\mathrm{I} 2}{\mathrm{r} 6}=\frac{\mathrm{x}}{\mathrm{r} \circ 0} \ldots \ldots . \mathrm{x}=75 \text { as percentage }\right]
$$

and categorized to three levels; poor $<50$, average $50-75$ and good $>75$. 
Data collection: A structured and selfadministered questionnaire was used for data collection. The data collection was carried out from the period of $15^{\text {th }}$ to $25^{\text {th }}$ June 2014.

Statistical analysis: Data was analyzed using the statistical package for the social sciences (version19). Chi-square test was used to find out the relationships between some selected variables andhealthcare providers knowledge and demographic characteristics.

Ethnic approval: Ethical approval was obtained from Hawler Medical University/ College of Nursing Research Ethics Committee on $6^{\text {th }}$ April 2014. Verbal approval was obtained from all respondents before being interviewed and each participant was notified about the purpose of the study, the right to refuse to participate in the study, and anonymity and confidentiality of the information gathered.

\section{Results}

Just more than one of third of participants were from Azadi PHCC (35\%), 31\% were in the age group 33-42 years old, 51\% were male, majority of them were married $(80 \%), 56 \%$ were institute graduates, $89 \%$ were living in urban area, $75 \%$ had 2-11 years of experience in PHCCs and $29 \%$ were working in vaccination rooms (Table 1).

Table 1: Socio-demographic characteristics of the respondents $(\mathrm{N}=100)$

\begin{tabular}{|c|c|c|}
\hline Variables & No. & $(\%)$ \\
\hline \multicolumn{3}{|l|}{ Working place } \\
\hline Azady & 35 & (35) \\
\hline Malafandy & 17 & (17) \\
\hline Tayrawa & 28 & (28) \\
\hline Zhyian & 20 & (20) \\
\hline \multicolumn{3}{|l|}{ Age } \\
\hline 23-32 years & 31 & (31) \\
\hline $33-42$ years & 38 & (38) \\
\hline 43-52 years & 26 & (26) \\
\hline$>52$ years & 5 & (5) \\
\hline \multicolumn{3}{|l|}{ Sex } \\
\hline Male & 51 & (51) \\
\hline Female & 49 & (49) \\
\hline \multicolumn{3}{|l|}{ Marital status } \\
\hline Single & 18 & $(18)$ \\
\hline Married & 80 & (80) \\
\hline Divorce & 2 & $(2)$ \\
\hline \multicolumn{3}{|l|}{ Qualification } \\
\hline High school & 33 & (33) \\
\hline Diploma & 56 & (56) \\
\hline Bachelor & 11 & (11) \\
\hline \multicolumn{3}{|l|}{ Address } \\
\hline Rural & 11 & (11) \\
\hline Urban & 89 & (89) \\
\hline \multicolumn{3}{|c|}{ Year of experience in PHCCs } \\
\hline 211-years & 75 & $(75)$ \\
\hline $12-21$ years & 17 & (17) \\
\hline Above 21 years & 8 & $(8)$ \\
\hline \multicolumn{3}{|l|}{ Working place } \\
\hline Vaccination Unit & 29 & $(29)$ \\
\hline Malnutrition Unit & 21 & $(21)$ \\
\hline Family Planning Unit & 16 & (16) \\
\hline Pharmacy Unit & 16 & (16) \\
\hline Laboratory Unit & 12 & (12) \\
\hline Birth Registration & 6 & (6) \\
\hline
\end{tabular}


More than half of participants (54\%) had average knowledge while $24 \%$ and $22 \%$ of them had poor and good knowledge, respectively (Table 2). Regarding the association between type of the PHCC and knowledge scores of the respondents, the health care providers working in Mala Fandi PHCC had higher knowledge scores $(76.5 \%)$ than those in other centers, which was statistically significant associations $(P>0.001)$ The health care providers that had $>$ 21years of experience in PHCCs had more average knowledge $(100 \%)$ than the other groups that was statistically significant $(P=0.049)$. There was no statistically significant association with age, gender, qualification and marital status (Table 3).

Table 2: Distribution of respondents according to their level of knowledge regarding Rotavirus vaccine

\begin{tabular}{llll}
\hline Level of Knowledge & Score in \% & No. & (\%) \\
\hline Poor & $<50$ & 24 & $(24)$ \\
Average & $50-75$ & 54 & $(54)$ \\
Good & $>75$ & 22 & $(22)$ \\
Total & & 100 & 100 \\
\hline
\end{tabular}

Table 3: Association between knowledge scores and selected socio-demographic characteristics

\begin{tabular}{lcccc}
\hline Variables & $\begin{array}{c}\text { Poor } \\
\text { No. (\%) }\end{array}$ & $\begin{array}{c}\text { Average } \\
\text { No. (\%) }\end{array}$ & $\begin{array}{c}\text { Good } \\
\text { No. (\%) }\end{array}$ & P value \\
\hline PHCC & $10(28.6)$ & $23(65.7)$ & $2(5.7)$ & \\
Azadi & $0(0.0)$ & $4(23.5)$ & $13(76.5)$ & $<0.001$ \\
Malafandi & $10(35.7)$ & $14(50.0)$ & $4(14.3)$ & \\
Tairawa & $4(20.0)$ & $13(65.0)$ & $3(15.0)$ & \\
Zhian & & & & \\
Age (in years): & $9(29.0)$ & $13(41.9)$ & $9(29.0)$ & \\
23-32 years & $11(28.9)$ & $18(47.4)$ & $9(23.7)$ & 0.216 \\
33-42 years & $3(11.5)$ & $19(73.1)$ & $4(15.4)$ & \\
43-52 & $1(20.0)$ & $4(80.0)$ & $0(0.0)$ & \\
$>52$ & & & & \\
Gender: & $11(21.6)$ & $30(58.8)$ & $10(19.6)$ & 0.614 \\
Male & $13(26.5)$ & $24(49.0)$ & $12(24.5)$ & \\
Female & & & & \\
Qualification: & $8(24.2)$ & $18(54.5)$ & $7(21.2)$ & \\
High school & $12(21.4)$ & $32(57.1)$ & $12(21.4)$ & \\
Diploma & $4(36.4)$ & $4(36.4)$ & $3(27.3)$ & \\
Bachelor & & & & \\
Marital Status: & $7(38.9)$ & $9(50.0)$ & $2(11.1)$ & \\
Single & $17(21.3)$ & $43(53.8)$ & $20(25.0)$ & 0.290 \\
Married & $0(0.0)$ & $2(100.0)$ & $0(0.0)$ & \\
Divorce & & & & \\
Year of experience in & $19(25.3)$ & $36(48.0)$ & $20(26.7)$ & 0.049 \\
PHCC & $5(29.4)$ & $10(58.8)$ & $2(11.8)$ & \\
2-11 years & $0(0.0)$ & $8(100.0)$ & $0(0.0)$ & \\
12-21 years & & & & \\
$>$ 21 years & & & & \\
\hline
\end{tabular}


The highest percentage of knowledge was seen in those working in the vaccination unit at the average level (69.0\%), but there was no statistically significant association between working place with knowledge $(P=0.133)$ as shown in Table 4.

\section{Discussion}

A recent report by the Centre for Disease Control noted that as rotavirus vaccine coverage increased, rotavirus seasons were shorter in durations and diminished in magnitude compared with pre-vaccine seasons. ${ }^{10}$ This study showed that more than half percentage of health care providers (54\%) had average knowledge, $24 \%$ had poor knowledge and $22 \%$ had good knowledge. The results are consistent with the results of a study done in Nigeria, which found that most healthcare providers were aware of rotavirus disease, especially as priority problem for child health. Majority knew that vaccination was the most effective preventive method; a fifth thought it was good hygiene and treatment with oral rehydration therapy. More than half were conversant with current rotavirus vaccines but mainly concerned about their newness, yet below three quadrants would vaccinate their children. ${ }^{14}$ However, our results were sharply contrasted to the results of a study conducted in the five countries of India, Indonesia, Thailand, Ukraine and Nicaragua that showed that knowledge of rotavirus was extremely low, and as a result was not considered a high priority. ${ }^{15}$ The finding of the current study showed that there was a significant association between primary PHCC and knowledge in which highest percentage of good knowledge was noted at Mala Fandi PHCCs $(76.5 \%, P<0.001)$. This means that the PHCC is an essential factor affecting healthcare providers' knowledge. There was a significant association between years of experience in PHCC with knowledge in which all those who had $>21$ years of experience had 100\% average knowledge. Therefore, experience is essential for the development of professional experts in any field. There was no significant association between participants' knowledge with age, gender, qualification and marital status. This reveals that healthcare providers' levels, age groups, and gender were not important factors if they do not improve their knowledge and skills; otherwise, all these factors will not be beneficial for client care. Although statistically there was no significant association between working places with knowledge, the highest percentage of knowledge was seen in vaccination unit at average level (69.0\%). This means that working in any place gives information about it more than others who working out of it. To my knowledge, this is the first study to assess knowledge of healthcare providers regarding rotavirus vaccine in Iraq and there are few studies conducted on knowledge of rotavirus worldwide. With the limited available literature on this topic, it is very difficult to compare this study with other studies.

Table 4: Association between knowledge with working place in PHCCs.

\begin{tabular}{lcccc}
\hline Items & $\begin{array}{c}\text { Poor } \\
\text { No. (\%) }\end{array}$ & $\begin{array}{c}\text { Average } \\
\text { No. (\%) }\end{array}$ & $\begin{array}{c}\text { Good } \\
\text { No. (\%) }\end{array}$ & P value \\
\hline Vaccination & $4(13.8 \%)$ & $20(69.0 \%)$ & $5(17.2 \%)$ & \\
Malnutrition & $9(42.9 \%)$ & $8(38.1 \%)$ & $4(19.0 \%)$ & \\
Family Planning & $4(25.0 \%)$ & $11(68.8 \%)$ & $1(6.3 \%)$ & 0.133 \\
Pharmacy & $4(25.0 \%)$ & $8(50.0 \%)$ & $4(25.0 \%)$ & \\
Laboratory & $2(16.7 \%)$ & $5(41.7 \%)$ & $5(41.7 \%)$ & \\
Birth Registration & $1(16.7 \%)$ & $2(33.3 \%)$ & $3(50.0 \%)$ & \\
Total & 24 & 54 & 22 & \\
\hline \hline
\end{tabular}




\section{Conclusions}

This study concluded that just more than half of participants were in average knowledge level regarding rotavirus vaccine. Statistically, there were significant associations between knowledge with PHCCs and years of experience in PHCC, while no significant association it with age, gender, qualification and marital status. Healthcare providers need to improve themselves through using updated knowledge and advance technology to serve to community and teaching programs can be conducted in PHCCs regarding rotavirus vaccine to improve their knowledge.

\section{Conflicts of interest}

The author reports no conflicts of interest.

\section{References}

1. Susan LW, Shelton MH. Maternal-child nursing care optimizing outcomes for Mothers Children families, $1^{\text {st }}$ ed. Philadelphia: FA Davis Company; 2009. P. 779.

2. World Health Organization. Global Immunization news: Introduction of Haemophilus Influenzae Type B and Rotavirus Vaccines in Expanded Programme on Immunization in Iraq. 2012. Available from: http://www.who.int/immunization/ GIN_February_2012.pdf. Accessed at 1st September 2014

3. Abdulrazzaq A, Aljeboory SK, Abdul Kareem S, Klena J. Two different diagnostic methods for detection of rotavirus in Iraqi young Children. Al-Anbar J Vet Sci 2011; 4(1):52.

4. Ahmed H M, Coulter J BS, Nakagomi O, Hart CA, Zaki JM, Al-Rabaty AA, et al. Molecular Characterization of Rotavirus Gastroenteritis Strains, Iraqi Kurdistan. Emerge Infect Dis 2006; 12(5):824.

5. Alrifai SB, Alsaadi A, Mahmood YA, Ali AA, AlKaisi LA. Prevalence and etiology of nosocomial diarrhea in children $<5$ years in Tikrit teaching hospital. E Mediterr Health J 2009; 15 (5):1113.

6. Hussein AM, Hassan MK. Rotavirus Infection among Hospitalized Children with Acute Watery Diarrhea in Basrah - Iraq. Bahrain Medical Bulletin 2000; 22 (4): 2.

7. Alani QA, Al-Rawi SA, Salih AK, Al-Mawla SO. Common Rota Virus Gastroenteritis in Children under 5 Years in Maternity and Children Teaching Hospital, western Iraq. Anb Med J 2012; 10 (1): 2.

8. AL- Khafaji Y AR, AL-Jiboury HJ. Detection of Rotavirus in diarrhea stool samples of children with acute gastroenteritis in Babylon governorate, Iraq Int Res J Microbiol 2013; 4(3): 85.
9. Abood WS, Al-Juboury SA, Al-Rodhan M A. The molecular epidemiology of rotavirus strains causing gastroenteritis in infant in the region of Mid Iraq. AL-Qadisiya Journal Vet Med Sci 2013; 12(1):123.

10. Centers for Disease Control and Prevention, Rotavirus Vaccine - Questions \& Answers; 2011. available from: http://www.cdc.gov/vaccines/vpdvac/rotavirus/vac-faqs.htm. Accessed at $20^{\text {th }}$ November 2013.

11. Strategic Advisory Group of Experts on Immunization, Detailed Review Paper on Rotavirus Vaccines; 2009. available from: ht t p://www.who.int/immunization/ sage/3_Detailed_Review_Paper_on_Rota_Vacci nes_17_3_2009.pdf. Accessed at $20^{\text {th }}$ November $201 \overline{3}$.

12. Cattaneo R, Engert SF, Gray D, Vineyard Ch. "Immunization Training Guide \& Practice Procedure Manual For Pediatricians, Physicians, Nurse Practitioners, Physician Assistants, Nurses, Medical Assistants, and Office Manager, By American Academy of Pediatrics"; 2012). PP. 12-13. Available from:

http://www2.aap.org/immunization/pediatricians/pdf/ immunizationtrainingguide.pdf. Accessed at $17^{\text {th }}$ July 2013.

13. Basic-mathematics.com. Formula for percentage; 2015. Available from: http://www.basic-mathematics.com/formula-forpercentage.html. Accessed at $23^{\text {rd }}$ July 2015.

14. Nnenna TB, Maduka $U$, Babatunde OI, Ihuarula E Ch, Anyele UN. Knowledge of Rotavirus Disease among Healthcare Providers and Their Acceptance of Rotavirus Vaccines in South-East, Nigeria. J Vaccines Vaccin 2013; S1:1005.

15. Simpson E, Wittet S, Bonilla J, Gamazina K, Cooley L, Winkler JL. "Use of formative research in developing a knowledge translation approach to rotavirus vaccine introduction in developing countries". BMC Public Health 2007; 7:281. 